\title{
Prostate - Specific Antigen, an Effective Screening Tool for Prostate Cancer - An Analysis of 932 TRUS Core Needle Biopsies
}

\author{
Kunjal Lila1, Kirti Chadha², Shaikhali M Barodawala³, Vikas S Kavishwar4, \\ Anuradha K Murthy ${ }^{5}$
}

${ }^{1}$ Doctor in Charge \& Consultant, Department of Surgical Pathology, Metropolis Healthcare Limited, Mumbai, India

${ }^{2}$ Chief Scientific Officer \& Senior Oncopathologist, Department of Surgical Pathology, Metropolis Healthcare Limited, Mumbai, India

${ }^{3}$ Scientific Business Head, Head of Department \& Consultant, Department of Surgical Pathology, Metropolis Healthcare Limited, Mumbai, India

${ }^{4}$ Senior Consultant, Department of Surgical Pathology, Metropolis Healthcare Limited, Mumbai, India \& Professor (Additional), Department of Pathology, T.N. Medical College, Nair Hospital, Mumbai, India

${ }^{5}$ Senior Consultant, Department of Surgical Pathology, Metropolis Healthcare Limited, Mumbai, India.

Corresponding Author: Kunjal Lila

DOI: https://doi.org/10.52403/ijhsr.20220305

\begin{abstract}
Prostate cancer is the second most frequent cancer and the fifth leading cause of cancer death among men in 2020. Since it is a slow growing tumour, an early detection leads to better chance of successful treatment. Prostate-Specific Antigen (PSA) is a protein found exclusively in prostatic tissue. It is elevated in different prostatic pathologies apart from carcinoma.

A cohort of 932 prostatic core needle biopsies was selected after necessary exclusions. The routine haematoxylin \& eosin and immunohistochemistry slides were retrieved along with the histopathologic diagnosis rendered. The diagnosis was then correlated with PSA.

The mean age for diagnosis of prostatic disease and carcinoma was 68.39 years and 70.21 years respectively. $50.50 \%$ cases were premalignant or malignant whereas the remaining $49.50 \%$ cases were benign. A cut-off of $4 \mathrm{ng} / \mathrm{ml}$ had a sensitivity of $99.78 \%$ and a specificity of $7.33 \%$. Gleason score 8 and 9 were most common, accounting for $56.39 \%$ of the malignant cases.

The present study showed a statistical correlation of age and PSA with prostatic carcinoma. PSA is a valid and sensitive marker and may be continued as an early marker for the screening of prostate cancer. The risk of cancer is minimal with a PSA less than $4 \mathrm{ng} / \mathrm{ml}$ whereas an elevated PSA is associated with pathology and hence even a borderline elevation should not be ignored. Due to a low specificity, PSA needs to be corroborated with DRE and transrectal ultrasonography followed by biopsy in cases with PSA > 4ng/ml.
\end{abstract}

Keywords: Prostate, Prostate - Specific Antigen, Prostatic Adenocarcinoma, Benign Prostatic Hyperplasia

\section{INTRODUCTION}

Diseases of the prostate range from inflammation to benign prostatic hyperplasia (BPH) to malignancy. BPH and carcinoma are increasingly frequent with advancing age. Prostate cancer is the second most frequent cancer and the fifth leading cause of cancer death among men in 2020..$^{[1]}$ It is usually a very slow growing cancer and most patients do not have significant symptoms until the cancer reaches an advanced stage. If detected early when it is 
still confined to the prostate gland, it has a better chance of successful treatment. Here comes the role of Serum Prostate-Specific Antigen (PSA) as a tool for efficient, easy and cost-effective method of screening for prostatic cancer. ${ }^{[2]}$ PSA is a protein found exclusively in prostatic tissue. ${ }^{[3]}$ Different prostatic pathologies lead to raised PSA levels apart from carcinoma.

The aims of present study are

1. to determine the age distribution of patients with prostatic lesions

2. to determine histologic types and their correlation with Serum PSA levels

3. to correlate the Serum PSA levels across the Gleason scores \& Grade Groups

4. to evaluate the utility of PSA as a screening test for Prostatic Carcinoma

\section{MATERIALS AND METHODS}

A 5-year retrospective study was carried out in a Global Reference Pathology Laboratory which gets samples from across 7 countries. A total 1524 prostate core needle biopsies were received in this period. All the biopsies which had Serum PSA levels available were included in the study. Inadequate biopsies, follow up cases, cases without Serum PSA, post therapeutic \& recurrent tumours were excluded. The final study cohort had 932 cases. The routine haematoxylin \& eosin slides and immunohistochemistry (IHC) slides where available of these cases were retrieved along with the pathologic diagnosis rendered. IHC used was a multiplex cocktail comprising CK5, CK14, p63 \& P504S (AMACR) in suspicious cases/ atypical small acinar proliferation (ASAP) to confirm the histologic diagnosis. Synaptophysin was used to assess neuroendocrine differentiation. The final histopathology diagnosis was then correlated with PSA levels.

\section{RESULT}

A total number of 932 cases were studied.

Age and prostatic disease: The age ranged from 20 to 97 years. The maximum number of cases were in the age group of 60 to 80 years accounting for $70 \%$ cases. Only $2.6 \%$ cases were seen below 50 years of age and $8.80 \%$ above 80 years of age (Table 1 ).

Table 1: Frequency of cases in different age groups

Table 1: Frequency of cases in different age groups
\begin{tabular}{|l|l|l|}
\hline Age interval (in years) & Frequency & Percentage $(\%)$ \\
\hline$<40$ & 3 & 0.32 \\
\hline $41-50$ & 22 & 2.36 \\
\hline $51-60$ & 171 & 18.35 \\
\hline $61-70$ & 346 & 37.12 \\
\hline $71-80$ & 308 & 33.05 \\
\hline$>80$ & 82 & 8.80 \\
\hline Total & 932 & 100 \\
\hline
\end{tabular}

\section{Distribution of cases across}

\section{histopathologic diagnoses:}

The 932 cases were segregated based on the histopathologic diagnosis. The distribution showed $50.54 \%$ malignant cases \& $49.46 \%$ benign cases. Further segregation showed 48.7\% Prostatic Adenocarcinoma, 25.8\% $\mathrm{BPH}$ with prostatitis, $10.52 \% \mathrm{BPH}, 8.15 \%$ benign prostatic tissue followed by lesser percentage of other diagnoses (Table 2).

Table 2: Percentage of cases and their histopathologic diagnosis

\begin{tabular}{|l|l|l|}
\hline Diagnosis & Frequency & Percentage \\
\hline ASAP & 14 & 1.50 \\
\hline HGPIN & 2 & 0.21 \\
\hline Prostatic adenocarcinoma & 454 & 48.71 \\
\hline BPH & 98 & 10.52 \\
\hline BPH with prostatitis & 241 & 25.86 \\
\hline $\begin{array}{l}\text { Nonspecific granulomatous } \\
\text { prostatitis }\end{array}$ & 1 & 0.11 \\
\hline Prostatic Abscess & 1 & 0.11 \\
\hline Prostatitis & 44 & 4.72 \\
\hline Small Cell Prostatic Carcinoma & 1 & 0.11 \\
\hline Negative for malignancy & 76 & 8.15 \\
\hline Total & 932 & 100 \\
\hline
\end{tabular}

Prostatic disease and PSA: A correlation of PSA level was done with the biopsies. Among the 932 cases, 35 cases had a PSA value between $0 \& 4 \mathrm{ng} / \mathrm{ml}, 238$ cases had a PSA value between $4 \quad \& \quad 10 \mathrm{ng} / \mathrm{ml} \quad \&$ remaining 659 cases had a PSA value of more than $10 \mathrm{ng} / \mathrm{ml}$ (Table 3).

Of the malignant cases, 66 cases had a PSA between $4 \mathrm{ng} / \mathrm{ml} \& 10 \mathrm{ng} / \mathrm{ml}, 404$ cases had a PSA of $>10 \mathrm{ng} / \mathrm{ml}$ and only one case had a PSA of $<4 \mathrm{ng} / \mathrm{ml}$. Of the 404 cases which had a PSA of $>10 \mathrm{ng} / \mathrm{ml}, 277$ cases had a PSA value $>30 \mathrm{ng} / \mathrm{ml}$. On the other hand, in benign lesions, most of the cases with Prostatitis had a raised PSA, with 
Kunjal Lila et.al. Prostate - specific antigen, an effective screening tool for prostate cancer - an analysis of 932 TRUS core needle biopsies.

most cases falling in the range of $4 \mathrm{ng} / \mathrm{ml}$ to $30 \mathrm{ng} / \mathrm{ml}$. (Table 4).

Table 3: Correlation of PSA with different prostatic pathologies

\begin{tabular}{|l|l|l|l|l|l|l|l|}
\hline Diagnosis/ PSA (ng/ml) & \multicolumn{1}{|c|}{$\mathbf{4}$} & $\mathbf{1 1} \mathbf{- 2 0}$ & $\mathbf{2 1} \mathbf{- 3 0}$ & $\mathbf{> 3 0}$ & Grand Total \\
\hline ASAP & & 8 & 2 & 4 & & 14 \\
\hline BPH & 9 & 44 & 32 & 5 & 8 & 98 \\
\hline BPH with prostatitis & 14 & 87 & 79 & 18 & 43 & 241 \\
\hline HGPIN & & 1 & & & 1 & 2 \\
\hline Negative for malignancy & 6 & 27 & 22 & 6 & 15 & 76 \\
\hline Nonspecific granulomatous prostatitis & & & 1 & & & 1 \\
\hline Prostatic Abscess & & & 1 & & & 1 \\
\hline Prostatic adenocarcinoma & 1 & 57 & 73 & 48 & 275 & 454 \\
\hline Prostatitis & 5 & 14 & 11 & 5 & 9 & 44 \\
\hline Small Cell Prostatic Carcinoma & & & & & 1 & 1 \\
\hline Grand Total & 35 & 238 & 221 & 86 & 352 & 932 \\
\hline
\end{tabular}

Table 4: PSA in benign and malignant cases

\begin{tabular}{|l|l|l|l|l|}
\hline & $<4 \mathrm{ng} / \mathrm{ml}$ & $4-10 \mathrm{ng} / \mathrm{ml}$ & $>10 \mathrm{ng} / \mathrm{ml}$ & Total \\
\hline Benign & $34(7.37 \%)$ & $172(37.31 \%)$ & $255(55.31 \%)$ & 461 \\
\hline Malignant & $1(0.21 \%)$ & $66(14.01 \%)$ & $404((85.78 \%)$ & 471 \\
\hline
\end{tabular}

The sensitivity and specificity and positive and negative predictive values were calculated with the cut-off point of $4 \mathrm{ng} / \mathrm{ml}$. Values under $4 \mathrm{ng} / \mathrm{ml}$ were taken as negative for malignancy and values over the cut off were taken as positive for malignancy. The histopathology report was taken as the gold standard (Table 5).

Table 5: Probability of PSA in detecting malignancy with 4 ng/ml as cut-off

\begin{tabular}{|l|l|}
\hline Sensitivity & $\mathbf{9 9 . 7 8 \%}$ \\
\hline Specificity & $\mathbf{7 . 3 3 \%}$ \\
\hline Positive Predictive Value & $\mathbf{5 2 . 0 6 \%}$ \\
\hline Negative Predictive Value & $\mathbf{9 7 . 1 4 \%}$ \\
\hline Diagnostic accuracy of test & $\mathbf{5 3 . 7 5 \%}$ \\
\hline
\end{tabular}

Distribution of malignant cases across Gleason scores and Grade Groups: Modified Gleason Grading System is the standard grading system in Prostatic Adenocarcinoma. ${ }^{[4]}$ This is based primarily on the growth pattern of neoplastic glands on low - power magnification. This system defines five patterns with decreasing differentiation and the sum of the most common primary pattern \& worst remaining pattern constitutes the Gleason score that ranges from 2 to 10 . Based on the Gleason score, a grade group is assigned as per new ISUP/WHO classification 2014 that ranges from 1 to $5 .{ }^{[4]}$ In our cohort of 454 cases, the commonest Gleason score was $8(4+4)$ with a grade group of 4 followed by Gleason score of $9(4+5 / 5+4)$ with grade group of 5 (Table 6).

Table 6: Distribution of malignant cases across Gleason scores and Grade Groups

\begin{tabular}{|l|l|l|l|}
\hline Gleason score & $\begin{array}{l}\text { Grade } \\
\text { Group }\end{array}$ & $\begin{array}{l}\text { Number of } \\
\text { cases }\end{array}$ & $\begin{array}{l}\text { Percentage } \\
(\%)\end{array}$ \\
\hline 6 & 1 & 81 & 17.87 \\
\hline $7(3+4)$ & 2 & 47 & 10.35 \\
\hline $7(4+3)$ & 3 & 66 & 14.54 \\
\hline 8 & 4 & 143 & 31.50 \\
\hline $9(4+5 / 5+4)$ & 5 & 113 & 24.89 \\
\hline 10 & 5 & 4 & 0.88 \\
\hline Total & & 454 & 100 \\
\hline
\end{tabular}

Gleason scores/ Grade groups and PSA: The PSA levels were compared to the Gleason scores. It was seen that higher Gleason scores had higher PSA levels (Table 7).

Table 7: Correlation of PSA with Gleason score

\begin{tabular}{|l|l|l|l|l|l|l|}
\hline \multirow{2}{*}{ PSA (ng/ml) } & \multicolumn{6}{|c|}{ Gleason score } \\
\cline { 2 - 7 } & $\mathbf{6}$ & $\mathbf{7}(\mathbf{3 + 4})$ & $\mathbf{7 ( 4 + 3 )}$ & $\mathbf{8}$ & $\mathbf{9 ( 4 + 5 / 5 + 4 )}$ & $\mathbf{1 0}$ \\
\hline$<4$ & & & & 1 & & \\
\hline $4-10$ & 28 & 6 & 9 & 9 & 8 & \\
\hline $11-20$ & 25 & 12 & 10 & 16 & 7 & \\
\hline $21-30$ & 5 & 5 & 15 & 16 & 5 & \\
\hline$>30$ & 23 & 24 & 32 & 101 & 93 & 4 \\
\hline Total & 81 & 47 & 66 & 143 & 113 & 4 \\
\hline
\end{tabular}

\section{DISCUSSION}

Carcinoma of prostate is a common cancer in India \& worldwide presenting a challenge to urologists, radiologists \& pathologists. The approach to its diagnosis has changed with emphasis on an early 
diagnosis while the process is still localised to the prostate. The gold standard triad for this comprises DRE, PSA level \& transrectal ultrasonography. ${ }^{[5]}$ The DRE has always been the primary method for evaluating the prostate, however, it is neither specific nor sensitive and has great inter-examiner variability. ${ }^{[6,7]}$

To improve the detection rate of carcinoma, the DRE should be aided by a test with high sensitivity and Serum PSA is one such test. The diagnosis of prostate cancer has increased substantially since the introduction of PSA screening. ${ }^{[8,9]}$
The serum PSA levels, however, can be influenced by other diseases like hyperplasia \& inflammation.

\section{Correlation of Prostatic carcinoma with} age: In the present study, the age ranged from 20 to 97 years. The maximum number of cases were in the age group of 60 to 80 years accounting for $70 \%$ cases. Only $2.6 \%$ cases were seen below 50 years of age and $8.80 \%$ above 80 years of age.

The mean age for diagnosis of prostatic disease was 68.39 years.

The mean age for diagnosis of prostatic carcinoma was 70.21 years which is similar to other studies (Table 8).

Table 8: Comparison of mean age (in years) of prostatic carcinoma with other studies

\begin{tabular}{|l|l|l|l|l|}
\hline $\begin{array}{l}\text { Present } \\
\text { study }\end{array}$ & $\begin{array}{l}\text { Gopinath Barui et al } \\
(2019)\end{array}$ & $\begin{array}{l}\text { Deepak Panasseril Jayapradeep et al } \\
(2017)^{[11]}\end{array}$ & $\begin{array}{l}\text { Vani BR et al } \\
(\mathbf{2 0 1 5})^{[12]}\end{array}$ & $\begin{array}{l}\text { Jasani et al } \\
(\mathbf{2 0 1 2})^{[13]}\end{array}$ \\
\hline 70.21 & 66.7 & 68.8 & 63.8 & 65.82 \\
\hline
\end{tabular}

The mean age for diagnosis for $\mathrm{BPH}$ was 66.55 years which is similar to the mean age of 63.77 years seen by Gopinath Barui et al. ${ }^{[10]}$

There was statistical correlation of age with prostatic carcinoma with a $\mathrm{p}$ value of 0.0001 .
Distribution of benign and malignant cases: In the present study, $50.50 \%$ cases were positive for either ASAP, PIN or carcinoma whereas the remaining $49.50 \%$ cases fell into the benign category. This is similar to that seen by Londhe et al (Table 9). ${ }^{[14]}$

\begin{tabular}{|c|c|c|c|c|}
\hline & Present study & Londhe et al (2018) ${ }^{[14]}$ & Varsha Khant et al (2017) ${ }^{[15]}$ & Vani BR et al (2015) ${ }^{[12]}$ \\
\hline Benign & $49.46 \%$ & $50.86 \%$ & $60.91 \%$ & $\mathbf{7 0 . 8 \%}$ \\
\hline Malignant & $50.54 \%$ & $49.14 \%$ & $37.27 \%$ & $29.2 \%$ \\
\hline
\end{tabular}

PSA levels and Prostatic carcinoma: Serum PSA is a tumour marker but its serum levels are under the influence of physiological and pathological processes and hence PSA is not highly specific for prostate carcinoma. Clinically applicable reference values for this marker are from 0 $4.0 \mathrm{ng} / \mathrm{mL}$, but they don't exclude carcinoma always. In the present study, one case having a PSA level less than $4 \mathrm{ng} / \mathrm{ml}$ had adenocarcinoma, rest all positive cases had a PSA value above $4 \mathrm{ng} / \mathrm{ml}$.

As per as study conducted by Ghafoori M et al (2009), a serum PSA above $4 \mathrm{ng} / \mathrm{ml}$ is an indication of prostatic biopsy. ${ }^{[16]}$

Intermediary or gray zone PSA values of 4 to $10 \mathrm{ng} / \mathrm{ml}$ can be present in patients with benign hyperplasia of prostate, prostatitis, intraepithelial neoplasia as well as in prostate carcinoma cases. ${ }^{[17]}$ Similar findings are seen in our study where cases with Prostatitis had a raised PSA, with most cases falling in the range of $4 \mathrm{ng} / \mathrm{ml}$ to 30 $\mathrm{ng} / \mathrm{ml}$.

In the current study, a statistical correlation of Serum PSA with prostatic carcinoma was established with a $\mathrm{p}$ value of 0.0001 .

In the present study, a cut off of 4 $\mathrm{ng} / \mathrm{ml}$ had a sensitivity of $99.78 \%$ and a specificity of $7.33 \%$. If the cut off was increased to $10 \mathrm{ng} / \mathrm{ml}$, the sensitivity was reduced to $85.89 \%$ and specificity was increased to $44.61 \%$. A high specificity and 
Kunjal Lila et.al. Prostate - specific antigen, an effective screening tool for prostate cancer - an analysis of 932 TRUS core needle biopsies.

low specificity is in sync with that observed in other studies (Table 10).

\begin{tabular}{|l|l|l|l|l|l|l|}
\multicolumn{9}{|c}{ Table 10: Comparison of sensitivity \& specificity of PSA with 4 ng/ml cut-off with other studies } \\
\hline & $\begin{array}{l}\text { Present } \\
\text { study }\end{array}$ & $\begin{array}{l}\text { Vani BR et } \\
\text { al (2015) }\end{array}$ & $\begin{array}{l}\text { Deepak } \\
\text { Jayapradeep et al (2017) } \\
{[11]}\end{array}$ & $\begin{array}{l}\text { Ghafoori M et } \\
\text { al (2009) }{ }^{[16]}\end{array}$ & $\begin{array}{l}\text { Mbaeri TU et } \\
\text { al }(2018)\end{array}$ & $\begin{array}{l}\text { Bannakij } \\
\text { Lojanapiwat } \\
(2014)\end{array}$ \\
\hline Sensitivity & $\mathbf{9 9 . 7 8 \%}$ & $\mathbf{1 0 0 \%}$ & $\mathbf{9 6 . 6 7 \%}$ & $\mathbf{9 3 . 4 \%}$ & $\mathbf{9 9 . 1 3 \%}$ & $\mathbf{9 8 . 0 \%}$ \\
\hline Specificity & $\mathbf{0 7 . 3 2 \%}$ & $\mathbf{3 8 . 1 \%}$ & $\mathbf{3 8 . 5 7 \%}$ & $\mathbf{1 5 . 3 \%}$ & $\mathbf{0 2 . 1 5 \%}$ & $\mathbf{0 9 . 3 \%}$ \\
\hline
\end{tabular}

$\begin{array}{llll}\text { Distribution of cases as per } & \text { Gleason } \\ \text { score: The cases of prostatic }\end{array}$ adenocarcinoma were graded according to the Modified Gleason Grading System and the new ISUP/WHO classification 2014. ${ }^{[4]}$ In the present study, Grade 4 and 5 (Gleason score 8 and 9) were most common, accounting for $56.39 \%$ of the malignant cases. Similar findings were also seen in study by Londhe et al in Grade 4 and 5 (Gleason score 8 and 9) accounted for $64.91 \%$ of the malignant cases. ${ }^{[14]}$ In the studies done by Atchyuta M et al (2016) \& Deepak Panasseril Jayapradeep et al (2017), the most common Gleason's score was 7 with Grade Group 3 in $43 \%$ \& $51.61 \%$ cases respectively, whereas in the study by Gopinath Barui et al (2019), Grade Group 3 and 4 (Gleason score 7 and 8) accounted for a total of $69.56 \%$ cases. ${ }^{[20,21,10]}$

\section{Correlation between PSA and Gleason} score: In our study, it was seen that higher Gleason scores had higher PSA levels. However, this trend was not seen in a significant cohort of cases, hence a statistical correlation between Gleason score and serum PSA level could not be established with a $p$ value of 0.7100 . This was similar to the study by Rashid et al. (2020), Londhe et al (2018) \& Gurumurthy $D$ et al (2015). [21,14,22] However, other studies like Atchyuta M. et al (2016), Karazanashvili G et al (2003) and Wei -Jen Shih et al (1992) showed that there is strong positive correlation between Gleason score given in prostatic adenocarcinomas and PSA values. ${ }^{[20,23,24]}$

\section{Limitations}

1. Inability to incorporate the PSA levels of all the study subjects
2. Serum PSA values obtained were not measured by the same method or on the same platform.

3. Inability to correlate the cases with other serum parameters like PSA velocity, PSA doubling time.

4. Lack of follow up assessment

\section{CONCLUSION}

There are very few studies comparing PSA levels with various prostatic lesions in core biopsies alone. Also, the sample size of the present study further increases the accuracy data of the study. The present study showed a statistical correlation of age with prostatic carcinoma with a $p$ value of 0.0001 . The mean age for diagnosis of prostatic disease was 68.39 years and of prostatic carcinoma was 70.21 years. The distribution of malignant and benign cases was $50.50 \%$ \& $49.50 \%$ respectively. A statistical correlation of PSA with prostatic carcinoma was established with a $\mathrm{p}$ value of 0.0001 . Grade 4 and 5 (Gleason score 8 and 9) were most common, accounting for $56.39 \%$ of the malignant cases. Although higher Gleason scores had higher PSA levels, a statistical correlation between Gleason score and PSA level could not be established with a $p$ value of 0.7100 . PSA had a sensitivity of $99.78 \%$ and a specificity of $7.33 \%$ with a diagnostic accuracy of $53.75 \%$ with a cut-off of 4 $\mathrm{ng} / \mathrm{ml}$. This showed that PSA is a valid and sensitive marker and may be continued as an early marker for the screening of prostate cancer. The risk of cancer is minimal with a PSA less than $4 \mathrm{ng} / \mathrm{ml}$ whereas an elevated PSA is associated with pathology and hence even a borderline elevation should not be ignored. Due to a low specificity, PSA needs to be corroborated with DRE and transrectal ultrasonography followed by 
Kunjal Lila et.al. Prostate - specific antigen, an effective screening tool for prostate cancer - an analysis of 932 TRUS core needle biopsies.

biopsy in cases with PSA > $4 \mathrm{ng} / \mathrm{ml}$ to conclude.

\section{Acknowledgement: None}

\section{Conflict of Interest: None}

\section{Source of Funding: None}

\section{Ethical Approval: Approved}

\section{REFERENCES}

1. Hyuna Sung, Jacques Ferlay, Rebecca L. Siegel et al. Global Cancer Statistics 2020: GLOBOCAN Estimates of Incidence and Mortality Worldwide for 36 Cancers in 185 Countries. CA CANCER J CLIN 2021;0:141

2. Labrie F, Dupont A, Suburu R et al. Serum prostate specific antigen as pre-screening test for prostate cancer. J Urol. 1992;147(3): 846-51

3. Oesterling JE. Prostate specific antigen: a critical assessment of the most useful tumor marker for adenocarcinoma of the prostate. J Urol. 1991;145(5):907-23

4. Humphrey P, Amin MB, Berney D et al. Acinar adenocarcinoma. In: Moch $\mathrm{H}$, Humphrey PA, Ulbright T, Reuter VE, eds. Pathology and Genetics: Tumors of the Urinary System and Male Genital Organs. 4th edition. WHO Classification of Tumors. Zurich, Switzerland: WHO Press; 2015:3-28

5. Franco O E, Arimak, Yanagwa $M$ et al. The usefulness of Power Doppler Ultrasonography for diagnosing prostate cancer: histological correlation of each biopsy site. Br J Urol 2000; 85:1049-52

6. U Nal D, Sedelaar Aarnik. Three dimensional contest enhanced Power Doppler Ultrasonography and conventional examination method: the value of diagnostic predictors of prostate cancer. $\mathrm{Br} \mathrm{J}$ Urol 2000;86:54-8

7. Vander EW, Wildhagen M.F, Schroder F.H. The value of current diagnostic tests in prostate cancer screening. Br. J Urol 2001; 88:458-66

8. Gelmann E P. Complexities of Prostate_cancer risk. New Engl J Med 2008;358(9):961-3

9. Wong N Y, Mitra N, Hudes $G$ et al. Associated with Treatment vs observation of localized prostate cancer in elderly men. JAMA 2006;296:2683-93

10. Gopinath Barui, Manas Talukdar, Tripti Das. Serum PSA and Grade-Grouping in TRUS-Guided Prostatic Biopsy. Gopinath Barui et al., Serum PSA and GradeGrouping in TRUS-Guided Prostatic Biopsy. Journal of Clinical and Diagnostic Research. 2019 Mar, Vol-13(3): EC05EC08

11. Deepak Panasseril Jayapradeep, V B Prakash, Thoppil Reba Philipose et al. Histomorphologic Correlation of PSA Levels in Prostatic Pathology. National Journal of Laboratory Medicine. 2017 Oct, Vol-6(4): PO28-PO32

12. Vani BR, Kumar D, Sharath BN et al. K. A comprehensive study of prostate pathology in correlation with prostate-specific antigen levels: An Indian study. Clin Cancer Investig J 2015;4:617-20

13. Jasmin H. Jasani, Himani B.Patel, Bijol Gheewala et al. Diagnostic utility of prostate specific antigen for detection of prostatic lesions. International Journal of Biomedical and Advance Research. (2012) 03(04); 268-272

14. Apurva Londhe, Anita Shah. Prostate Specific Antigen (PSA) Levels and its Correlation to Prostatic Lesions. Annals of Pathology and Laboratory Medicine, Vol. 5, Issue 11, November, 2018, A894-99

15. Varsha S Khant, Hansa Goswami, Pooja Y Shah. Correlation of serum prostate-specific antigen level in various prostate pathology in elderly men. Journal of Medical Science and Public Health. 2017;6(2):257-61

16. Ghafoori M, Varedi P, Hosseini SJ et al. Value of prostate-specific antigen and prostate-specific antigen density in detection of prostate cancer in an Iranian population of men. Urol J. 2009;6(3):182-88

17. Zivkovic S. Correlation between prostatespecific antigen and histopathological difference of prostate carcinoma. Arch Oncol. 2004;12(3):148-51.

18. Mbaeri TU, Nwadi U, Abiahu JA et al. Correlation between prostate specific antigen, digital rectal examination and histology inpatients with prostate cancer. Nigerian Journal of Medicine, Vol. 27 No. 3, July - September, 2018: 212-218.

19. Lojanapiwat B, Anutrakulchai W, Chongruksut $\mathrm{W}$ et al. Correlation and diagnostic performance of the prostate- 
Kunjal Lila et.al. Prostate - specific antigen, an effective screening tool for prostate cancer - an analysis of 932 TRUS core needle biopsies.

specific antigen level with the diagnosis, aggressiveness, and bone metastasis of prostate cancer in clinical practice, Prostate International, Volume 2, Issue 3,2014,Pages 133-139

20. Atchyuta. M, R. Krishna, P. Prema Latha et al. Histological Spectrum of Prostatic Adenocarcinomas in Correlation with PSA Values. Indian Journal of Pathology and Oncology. 2016;3(March):2-7

21. N Rashid, UC Dutta, MLA Rahman et al. Histomorphological spectrum of prostatic lesions and their correlation with serum prostate-specific antigen level. International Journal of Health Research and MedicoLegal Practice; 2020 Jul 30;6(2):15-20.

22. Gurumurthy D, Maggad R, Patel S. Prostate carcinoma: correlation of histopathology with serum prostate specific antigen. Sci J Clin Med. 2015;4(4-1):1-5

23. Karazanashvili G, Abrahamsson AP. Prostate specific antigen and human grandular kallikrein in early detection of prostate cancer. J Urol. 2003;169:445-57

24. Wei-Jen S, Kelly G, Bonnie M, Judith C et al. Journal Of the National Medical Association. 1992;84:1049-1050

How to cite this article: Lila K, Chadha K, Barodawala SM et.al. Prostate - specific antigen, an effective screening tool for prostate cancer an analysis of 932 TRUS core needle biopsies. Int J Health Sci Res. 2022; 12(3): 32-38. DOI: https://doi.org/10.52403/ijhsr.20220305 